\title{
Folklorism and Classical Tradition in László Lajtha's Late String Quartets ${ }^{1}$
}

\author{
Viktória OzsváRT \\ Institute for Musicology, Research Centre for the Humanities \\ of the Hungarian Academy of Sciences \\ Táncsics Mihály u. 7., H-1014 Budapest, Hungary \\ E-mail: Ozsvart.Viktoria@btk.mta.hu
}

(Received: December 2017; accepted: March 2018)

\begin{abstract}
The gains from the folk music collection movement initiated by Béla Bartók and Zoltán Kodály in the first decade of the twentieth century set a path for Hungarian music theory that continued to influence the approach to composition in later decades. Placing folklore material in composed, classical works is complicated by tonal and formal problems and by political overtones. For quotations or thematic material from folk music may introduce complex implications and associations. So the way a composer imbues folk music calls for more than mere technical skill - it embodies an artistic statement. This article analyzes two works by the Hungarian composer and ethnomusicologist László Lajtha (1892-1963): his string quartets nos. 7 and 10 completed in the early 1950s. Through these two quartets I attempt to fathom the aesthetic, ideological and personal motives behind Lajtha's use of folk material in classical composition. Analysis of the composing process involved and the reception the two works received reveal the manifold scope that folk music brings as a source of inspiration.
\end{abstract}

Keywords: László Lajtha, folk music, string quartets

It has become a musicological cliché to associate the surge of folk-music collecting instigated by Béla Bartók and Zoltán Kodály in the first decade of the twentieth century with a new path for Hungarian musicology and composition. ${ }^{2}$ As remarked by Bence Szabolcsi, a former pupil of Kodály and founding father of

1. This publication has been supported by the New National Excellence Program of Hungary's Ministry of Human Capacities (ÚNKP-18-3) and by a scholarship of the Hungarian National Research, Development and Innovation Office (K 123819).

2. László Eősze, "Egy nemzeti zeneszerző egyetemessége" [The universality of a national composer], in id., Örökségünk, Kodály. Válogatott írások [Our heritage Kodály. Selected writings] (Budapest: Osiris, 2000), 175-183. 
Hungarian musicology: "Both [Bartók and Kodály] saw Hungarian folk music as classical art." ${ }^{3}$ So it is no surprise that the gains of the collecting movement both influenced the discourses in Hungarian musicology and refreshed the composing style of a new generation. For this hitherto unappreciated melodic trove gave a new outlook to young composers who themselves often worked as collectors: Bartók, Kodály and the tradition they generated served as a guide for later generations of their students, direct and indirect.

Yet the presence of folklore inspiration in composed music is far from evident or easily explained. Melodic quotations or thematics may contain complex meaning, associative strata that often need careful examination. To grasp its many interpretations requires looking at the historical context of each piece. The radical political changes in the twentieth century led to essential changes in the meaning and worth attached to Hungarian folk music and to compositions that embraced it. So the way a composer uses motivics borrowed from folk music reveals more than technical skill; it can be seen as an artistic statement.

This study analyzes two works by the Hungarian composer László Lajtha (1892-1963), whose œuvre shows many features reflecting aesthetic, ideological and personal motives behind his use of folk material. Lajtha belonged to a generation right after Bartók and Kodály. It should be remembered he was not only a composer but an ethnomusicologist, indeed among the first young musicians to join in the movement to collect folk music. From 1911 until his death he continued to gather and publish the collected material as intensively as conditions allowed. This field work in ethnomusicology fed to him some essential folk-music publications and collections. ${ }^{4}$

The two works examined here, the string quartets nos. 7 and 10, are both structured within classical generic frames, explicitly incorporate folklore, even quoting collected folk tunes. Part 1 gives some overall information about the quartets and their place in Lajtha's œuvre, while Part 2, helped out by his writings, sets out to sum up Lajtha's view on folk-music arrangement, the relationship between folk music and classical art, and the permeability of the two fields. After that examination of Lajtha's theoretical viewpoint, Parts 3 and 4 focus on the musical features of the two compositions, particularly the techniques for fusing the folklore material into the classical genre, several aspects of the connection between them, and the various ways in which folk material lends itself to the various aims of the compositions. In looking for the motivation behind the String Quartet no. 7, I ask if it was an experiment to find an acceptable compromise in a current musico-political

3. Bence Szabolcsi, "Kodály emlékezete” [Kodály’s memory], in Ferenc Bónis (ed.), Magyar zenetörténeti tanulmányok Kodály Zoltán emlékére [Studies in Hungarian music history in memory of Zoltán Kodály] (Budapest: Zenemükiadó, 1977), 13.

4. E. g. the series of Népzenei monográfiák [Folk music monographs], vols. 1-5, edited by Lajtha and published by the Budapest Zenemükiado from the first half of the 1950s onward. 
context, or whether Lajtha saw it as a musical joke. I also give an interpretation of the deep personal experience that inspired Lajtha's String Quartet no. 10, using folk music he had collected himself from the Transylvanian village Körispatak (Crișeni, Romania). The musical and archival sources cited in the study belong to Lajtha's estate, which is held at the Institute of Musicology, Research Center for the Humanities of the Hungarian Academy of Sciences (hereafter H-Bami).

\section{The string quartet genre in Lajtha's œuvre}

Alongside his ethnomusicological activity, Lajtha cultivated several classical genres. His œuvre contains traits and elements that stem from several historical ages and musical styles. These many features make his work of great interest to researchers into the mechanisms of influence and the history of musical genres. While in his early period he mainly composed piano solo and chamber music, he turned in his late creative period (1945 to 1963) to genres with a representative, traditional history ${ }^{5}$ - symphonies, liturgical music and quartets in particular. Six of his nine symphonies and four of his ten quartets derive from those years.

It should be noted that 1949 to 1956 was a period of detailed, dictatorial Stalinism in Hungary, in which liturgical music was disfavored. Not so much work was based on folk music. This was in vogue as a kind of faked national feeling, so much so that Kodály's musical idiom, recently dubbed "folkloristic national classicism," almost became the era's official style. ${ }^{7}$ Yet the change in generic preference in Lajtha can also be seen in practical terms; his former students at the Budapest National Conservatory - conductor János Ferencsik and violinist Vilmos Tátrai and his quartet - proved faithful performers of his works.

There is no typical string-quartet structure to be found in the works of László Lajtha. Each has some special features, and the composer draws on the same problem with different results - as with nos. 5 and 6 or nos. 8 and 9, which can be described as pairs. ${ }^{8}$ Furthermore all these quartets have something in common: they represent several ways in which the material borrowed from folk music can

5. Melinda Berlász, "Müfajszerű gondolkodás Lajtha László zenei életművében” [Generic thinking in the compositional œuvre of László Lajtha], Magyar Zene 31/1-2 (1990), 99-107 (Part 1) and 193-200 (Part 2).

6. Anna Dalos, "Folklorisztikus nemzeti klasszicizmus: egy fogalom elméleti forrásairól" [Folkloristic national classicism: on the theoretical sources of a concept], in Kodály és a történelem. Tizenkét tanulmány [Kodály and history. Twelve studies] (Budapest: Rózsavölgyi, 2015), 139-146.

7. Lóránt Péteri, "Kodály az államszocializmusban (1949-1967)" [Kodály under state socialism], in Melinda Berlász (ed.), Kodály Zoltán és tanítványai. A hagyomány és a hagyományozódás vizsgálata két nemzedék életmüvében [Zoltán Kodály and his pupils: Study of tradition and traditionalism in the œuvres of two generations] (Budapest: Rózsavölgyi, 2007), 105.

8. String quartet nos. 5 and 6 are called études; both require major technical skills from quartet players. String quartet nos. 8 and 9 were dedicated to Lajtha's two sons and their wives. All his string quartets have been recorded by the Auer String Quartet (4 CDs released in 2007, 2009 and 2011 by Hungaroton, 32542-32545). Table 1 gives durations on these recordings and the scores of the works in Lajtha's estate preserved at $\mathrm{H}-\mathrm{Bami}$. 
TABLE 1 The quartets of László Lajtha

\begin{tabular}{|c|c|c|c|c|}
\hline Quartet & Composed & \begin{tabular}{|l|} 
First \\
performed
\end{tabular} & Duration & Movements \\
\hline No. 1 (op. 5) & 1923 & $?$ & $19^{\prime} 57^{\prime \prime}$ & $\begin{array}{l}\text { 1. Adagio } \\
\text { 2. Presto }\end{array}$ \\
\hline No. 2 (op. 7) & 1926 & $\begin{array}{l}\text { 1928.04.23., } \\
\text { Budapest }\end{array}$ & $27^{\prime} 57^{\prime \prime}$ & $\begin{array}{l}\text { 1. Andante } \\
\text { 2. Presto alla marcia } \\
\text { 3. Molto andante } \\
\text { 4. Vivace } \\
\end{array}$ \\
\hline No. 3 (op. 11) & 1929 & $\begin{array}{l}\text { 1931.10.16., } \\
\text { Budapest }\end{array}$ & $\begin{array}{l}\text { 20’02', } \\
\text { Part.: } \\
18^{\prime} 00^{\prime}\end{array}$ & $\begin{array}{l}\text { 1. Andante } \\
\text { 2. Allegro } \\
\text { 3. Commodo } \\
\text { 4. Poco lento } \\
\text { 5. Vivo }\end{array}$ \\
\hline No. 4 (op. 12) & 1930 & $?$ & $17^{\prime} 47^{\prime \prime}$ & $\begin{array}{l}\text { 1. Allegro energico } \\
\text { 2. Molto andante } \\
\text { 3. Il più presto possibile } \\
\text { 4. Lento (Deux strophes et } \\
\text { ritournelle) } \\
\text { 5. Vivo e grazioso }\end{array}$ \\
\hline $\begin{array}{l}\text { No. } 5 \text { entitled } \\
\text { "Cinq études pour } \\
\text { quatuor à cordes" } \\
\text { (op. 20) }\end{array}$ & 1934 & \begin{tabular}{|l}
1948, \\
London, \\
Hurwitz \\
Quartet
\end{tabular} & $21^{\prime} 05^{\prime \prime}$ & $\begin{array}{l}\text { 1. Allegro vivo e energico (Rythme } \\
\text { et plénitude sonore) } \\
\text { 2. Andante. Comme une Valse très } \\
\text { lente (Jeu « Piano » et Délicatesse } \\
\text { de touche) } \\
\text { 3. Presto molto (Vélocité légère) } \\
\text { 4. Poco adagio (Polyphonie) } \\
\text { 5. Alla marcia (Pizzicato) }\end{array}$ \\
\hline $\begin{array}{l}\text { No. } 6 \text { entitled } \\
\text { "Quatre études } \\
\text { pour quatuor à } \\
\text { cordes" (op. 36) }\end{array}$ & 1942 & $\begin{array}{l}\text { 1948, } \\
\text { London (?) }\end{array}$ & $25^{\prime} 06^{\prime \prime}$ & $\begin{array}{l}\text { 1. Molto allegro } \\
\text { 2. Lento } \\
\text { 3. Gracieux et gai } \\
\text { 4. Prestissimo }\end{array}$ \\
\hline No. 7 (op. 49) & 1950 & $\begin{array}{l}\text { June 2, } \\
1951, \\
\text { Budapest }\end{array}$ & $20^{\prime} 05^{\prime \prime}$ & $\begin{array}{l}\text { 1. Prestissimo } \\
\text { 2. Molto tranquillo } \\
\text { 3. Menuet. Quasi allegro, grazioso } \\
\text { 4. Molto vivace }\end{array}$ \\
\hline No. 8 (op. 53) & 1951 & $\begin{array}{l}\text { April 29, } \\
1952, \\
\text { Budapest }\end{array}$ & $24^{\prime} 09^{\prime \prime}$ & $\begin{array}{l}\text { 1. Allegro } \\
\text { 2. Lent } \\
\text { 3. Capriccio. Tendrement } \\
\text { avec beaucoup de délicatesse } \\
\text { 4. Presto } \\
\end{array}$ \\
\hline No. 9 (op. 57) & 1953 & $\begin{array}{l}\text { November } \\
\text { 20, 1953, } \\
\text { Budapest }\end{array}$ & $\begin{array}{l}265^{\prime} \prime \\
\text { Part.: } \\
\text { environ } \\
23\end{array}$ & $\begin{array}{l}\text { 1. Très vif et accéléré } \\
\text { 2. Lent } \\
\text { 3. Menuet. Allegretto } \\
\text { 4. Entraînant et d'un seul élan }\end{array}$ \\
\hline $\begin{array}{l}\text { No. } 10 \text { entitled } \\
\text { "Suite transylvaine } \\
\text { en trois parties" } \\
\text { (op. 58) }\end{array}$ & 1953 & $\begin{array}{l}\text { June 2, } \\
1955, \\
\text { Budapest }\end{array}$ & 21'33"' & $\begin{array}{l}\text { 1. Première partie - Très lent } \\
\text { 2. Deuxième partie - Légér et volant } \\
\text { 3. Troisième partie - Lent mais } \\
\text { allant - Vif }\end{array}$ \\
\hline
\end{tabular}


be fused with a traditional form inherited from classical genres. Beside many pieces from Hungarian music history, the string quartets of Hector Villa-Lobos (1887-1959) could likewise have served Lajtha as an inspiration.

Born in South America, Villa-Lobos made many journeys to Europe, especially France. During a sojourn in Paris from 1927 to 1930, he became acquainted with the French critic and composer Florent Schmitt (1870-1958). ${ }^{9}$ Both belonged to the same circles and so it is possible Schmitt was informed about the VillaLobos quartets. Furthermore, a concert leaflet in the Lajtha collection confirms a connection, even a friendship between the two composers. A concert was held in Paris on May 23, 1956, in the Salle Chopin-Pleyel, where a French quartet played Lajtha's String Quartet no. 7. Lajtha was unable to appear, as he was forbidden for political reasons to travel abroad in those years. However, his colleagues sent him a signed leaflet of the concert with Villa-Lobos among the eleven signatories. There was a note added: "All your friends are happy to have heard your beautiful quartet." 10 Villa-Lobos's seventeen string quartets often use folklore material as well, or even center on it. They relate to Lajtha's in their unbounded handling of the musical form.

\section{Lajtha on the relations between folk music and art music}

A mere fusion of folk music and classical music in a work may pose several questions about the functions of the two fields. Relevant here is a paper written by the composer, found in his estate and thought to date from 1948, in which he remarks:

There has always been a relation between folk music and grand art and an important difference is always recognisable. Genuine folk music serves ritual, social and mystical aims, while classical music is always aesthetic. ${ }^{11}$

In what follows, Lajtha outlines two possible approaches. The first estimates folk music and folk song by their aesthetic value. The other, the scholarly viewpoint, assigns functionalism and historical importance as the essence of folk music. In

9. Eero Tarasti, "Villa-Lobos's String Quartets," in Evan Jones (ed.), Intimate Voices. The TwentiethCentury String Quartet (University of Rochester Press, 2009), 223-255; Lisa M. Peppercorn, "H. Villa-Lobos in Paris," Latin American Music Review 6/2 (Autumn-Winter 1985), 235-248; Antoine E. Cherbuliez, "L'Adaptation du folklore brésilien au style de J.-S. Bach selon la thèse de Villa-Lobos," Journal of the International Folk Music Council 9 (1957), 29-31.

10. "Tous les amis sont heureux d'avoir entendu Votre beau quatuor." Program sheet of a concert held in Paris on 23 May, 1956. Lajtha's estate (H-Bami, no shelf mark).

11. László Lajtha, “A népzene alkotói megközelítésének különbözőségei Bartóknál, Kodálynál és saját zenémben" [Different approaches to folk music in the music of Bartók, Kodály and myself], in Melinda Berlász (ed.), Lajtha László összegyüjtött írásai [Collected writings of László Lajtha] (Budapest: Akadémiai Kiadó, 1992), vol. 1, 130-135. An English title was added to an untitled Hungarian text by Lajtha's wife. 
both cases, ritual and social importance is seen as quite separate from aesthetic value. However, Lajtha notes the possibility of an overlap between these fields. He quotes Bartók on regarding certain folk songs as little artifacts. ${ }^{12}$ With folk-song arrangement, Lajtha emphasizes the importance of the accompaniment. For folk songs have a place in the concert hall as arrangements - that is the only way for them to become known to a larger public. ${ }^{13}$ Quoting Bartók again, he compares choral arrangement to folk-song arrangement. Lajtha remarks that the richness and diversity observed in early choral arrangement show the manifold scope open also to folk-song arrangement. Indeed, he sees this as the only approach to it. In the same paper Lajtha goes on to consider the ideological background:

It would be easy to say that folk music gained a bigger role in classical music due to rising nationalism. But there is another, subtler line, sometimes hard to notice, but a very strong, electric wire that binds the two fields - folk music and classical music. Folk music always belongs to a community, and so is a collective art that works within types inherited from that community. The other kind of music belongs to individuals. [Its] value depends on the genius of its creator: the composer. It is understandable psychologically that every single artist who creates his own psychological world, feels a need to belong somewhere. ${ }^{14}$

Lajtha refers more obliquely to the role of nationalism in binding folk music and classical music together. It is likely that the political and historical circumstances led him distinguish this phenomenon. More than two decades earlier, in 1923, Kodály gave an interview to Magyar Dal, in which he explained the connection between folk music and classical music simply in terms of nationalism becoming stronger and stronger. ${ }^{15} \mathrm{He}$ describes the way classical music had been renewed through elements learned from folk music as a characteristic, evolutionary tendency, and concludes: "As with nationalism becoming stronger all round, so this tendency will take a long time." ${ }^{.16}$ Lajtha and Bartók also took part in that

12. Lajtha names no source, but the idea can be found in the Preface to Bartók's Hungarian folk songs released in 1924. For a critical edition of Bartók's writing, see Bartók Béla írásai [Béla Bartók's writings], vol. 5: A magyar népdal [The Hungarian folk song], ed. Dorrit Révész (Budapest: Editio Musica, 1990), 11.

13. In 1928 a culture ministry campaign led to a series of gramophone recordings. The project, called His Master's Voice, contained arrangements by Bartók and Kodály, and by Lajtha, who spoke on it to the Hungarian Ethnological Society. A written version ensued in 1929 in the periodical Muzsika. László Lajtha, "A kultuszminisztérium gramofonakciója" [The gramophone campaign of the Ministry of Culture], Melinda Berlász (ed.), Lajtha László összegyüjtött írásai, vol. 1, 40-44.

14. Lajtha, “A népzene alkotói megközelitésének különbözőségei,” 130-131.

15. Zoltán Kodály, "A magyar dalkincs" [The Hungarian stock of song], Ferenc Bónis (ed.), Visszatekintés, vol. 3 (Budapest: Argumentum, 2007), 17. The original 1923 interview has three declarations, but Bónis published only Kodály’s. The whole article appears in Ernö Fábián, "A magyar dalkincs," Magyar Dal 38/5 (May 1923), 1-4.

16. Ibid., 2-3. 
interview. ${ }^{17}$ Lajtha spoke about the folk collection of the National Museum, while Bartók sketched the systemic principles for use in collecting folk material.

In the last part of his 1948 paper, Lajtha attempted to define what is called folklore imaginaire. He speaks of his own works and their possible folklore roots, and concludes with an example from them, a string quartet. Unfortunately, no information survives as to which string quartet - or which part of it - was played as an illustration. It is not even sure whether the interpretation rested on a whole piece or just a fragment. It can only be guessed that String Quartet no. 5 or no. 6 was performed. Notwithstanding, Lajtha's text emphasizes the essential difference between ritual or collective folk music and aesthetic, individualistic classical music. He makes it clear that the two genres belong to essentially different ranges of function. Despite this difference, Lajtha himself used folk songs or other folk material in some of his compositions. In what follows I set out to show some possible ways of doing so and explore the meaning in which they entwine folk music and classical music.

\section{String Quartet no. 7}

Lajtha completed his String Quartet no. 7 in 1950. It was a success at the First Hungarian Music Week, held in the autumn of 1951. The newspaper coverage of the time shows it was then played by Tátrai and his quartet many times in Hungary and abroad, too. According to Tátrai's report, a review of their Soviet concert tour in 1953 emphasized its success among the public, but the author also asserted: "[Though] the string quartet may be beautiful, it could contain deeper matters." 18 Hungarian critics appraised Lajtha's work enthusiastically. They emphasized its tone, which was described as "wonderfully fresh and simple in a folkloric way,"19 also "its melodies fertilized by folk music," ${ }^{20}$ or "the simple, clear, painted harmonies" ${ }^{21}$ that merge together. It should be noted that all these are characteristic of the style of the Kodály school. Under such circumstances, it is hardly surprising that Lajtha's work even won the sympathy of Ferenc Szabó, director of the Association of Hungarian Musicians and an aggressive political ideologist. ${ }^{22}$

17. Ibid., 2-4.

18. Károly Kristóf, "Hazaérkeztek a Szovjetunióban járt magyar művészek. Tátrai Vilmos beszámol a háromhetes hangversenykörútról" [Hungarian artists visiting the Soviet Union have arrived home. Vilmos Tátrai reports on the three-week concert tour], Magyar Nemzet 9/304 (2 December 1953), 29.

19. "sz. i." [István Szelényi], "Bartók Fesztivál. A Tátrai vonósnégyes estje” [Bartók Festival. Concert evening of the Tátrai String Quartet], Magyar Nemzet 14/232 (2 October 1958), 4.

20. István Raics, "Magyar művek a Tátrai vonósnégyes estjén" [Hungarian works at the evening of the Tátrai String Quartet], Népszabadság 16/235 (4 October 1958), 4.

21. Ibid.

22. Ferenc Szabó, “Az I. Magyar Zenei Héten bemutatott müvek” [Works presented at the First Hungarian Music Week], Új Zenei Szemle 2/12 (December 1951), 12-27. 
The composition appears to bind folklore and classical tradition together, and in a sense can be seen as an attempt to find an acceptable compromise with the new, restructured musico-political life. Earlier works of Lajtha share some features of the folkloric style of the Kodály school, but the String Quartet no. 7 conforms to it yet more closely. It was a method from which Lajtha would distance himself in his later creative period, so that he seems to have been conducting a kind of experiment at the beginning of a new era under a new social structure. In striving for an acceptable compromise, he gave his 1950 string quartet a clear and regular form, but even with some irony in the sense defined by Robert Hatten, as being borne of the tension between a certain statement or deed and the reality it contradicts. With Lajtha's string quartet, the irony reveals itself in a simplicity and clarity of form strangely at variance with the context of his whole œuvre. ${ }^{23}$

String Quartet no. 7 brings folklore motifs and associations into a structure well known from classical style. The work has four movements, whose character follows the generic tradition, while the thematic material derives from Hungarian folk music. The first movement, an allegro in traditional first-movement sonata form, is followed by a second that recalls a lament. The third is a minuet, and the final movement evokes the character of a folk-dance suite. The harmonization throughout is based on classical harmony. The melodic lines contain easily comprehensible units that are somewhat symmetrical and easy to follow. The sonata form in the first movement is so clear that Lajtha seems to show wry humor in structuring the work so simply, not least because he had expressed many times his antipathy to the strict and regular sonata form, criticizing it as unnatural and rigid. Although his statements on the subject were made in the second half of the 1950 s, the lack of sonata form and the unusual, free structures in his other works make us suspect that his views may have been the same in 1950. (For a structural overview of the first movement, see Table 2.)

No such strict sonata form as this would appear in Lajtha's late creative period, but here everything is in its place. The first and second themes and closing theme can be recognized easily and resemble classical sonata expositions. The development section is quite short, but easily identified. The recapitulation starts in B major, but soon reaches the tonic, so that the closing theme appears in D major. The sonata ends with a brilliant coda. Lajtha himself acknowledged the work's formal regularity. Seven years later, on May 22, 1958, he was talking with a former pupil, John S. Weissmann about his unconventional structure building when he added: "Nor do I reject the conventional sonata form - just remember my String Quartet no. 7." ${ }^{24}$ Although Lajtha makes no mention of irony in that letter - possibly no such remark could be safely made in the late $1950 \mathrm{~s}-$ it is worth noting that the

23. Robert Hatten, Musical Meaning in Beethoven. Markedness, Correlation and Interpretation Advances in Semiotics (Indiana University Press, 1994), 172.

24. Lajtha's letter to John S. Weissmann on May 22, 1958 (H-Bami, shelf mark: MZA-LL-Script 8.464:1). 
TABLE 2 String Quartet no. 7: the structure of mov. 1

\begin{tabular}{|c|c|c|c|c|c|}
\hline mm. 1-20 & mm. 21-45 & mm. 47-62 & mm. 63-115 & mm. 116-155 & mm. 156-179 \\
\hline $\begin{array}{l}\text { 1st theme } \\
p, \text { leggiero }\end{array}$ & $\begin{array}{l}\text { 2nd theme } \\
\text { pp, } \\
\text { dolcissimo, } \\
\text { cantabile }\end{array}$ & $\begin{array}{l}\text { Closing } \\
\text { theme } \\
m f, f, \\
\text { spiccato }\end{array}$ & $\begin{array}{l}\text { Development } \\
f f \rightarrow p p \rightarrow f f\end{array}$ & $\begin{array}{l}\text { Recapitulation } \\
p\end{array}$ & $\begin{array}{l}\text { Coda } \\
\text { sempre } p \text { e } \\
\text { spiccato }\end{array}$ \\
\hline $\begin{array}{l}\mathrm{D} \rightarrow \mathrm{F} \\
\rightarrow \mathrm{G}\end{array}$ & $\begin{array}{l}\mathrm{A} \rightarrow \mathrm{c} \rightarrow \mathrm{E} \\
\rightarrow \mathrm{g} \rightarrow \mathrm{d}\end{array}$ & $\mathrm{D} \rightarrow \mathrm{A}$ & $\begin{array}{l}\mathrm{a} \rightarrow \text { A flat } \\
\rightarrow \mathrm{B} \rightarrow \mathrm{f}\end{array}$ & $\mathrm{B} \rightarrow \mathrm{D}$ & $\begin{array}{l}\mathrm{D}(\rightarrow \text { A flat } \\
\rightarrow) \mathrm{D}\end{array}$ \\
\hline
\end{tabular}

composer himself cites only this one instance of a conventional sonata form in his whole œuvre.

The second movement reveals another strange solution that can be seen as a kind of parody: a palindromic form centered on a Hungarian folk tune. The telltale beginning of the text in the original song translates as "I am a poor lad." The melody is strangely transformed, with an originally minor theme given a major ending. The harmonic change is underlined by a rhythmic spread: instead of eighth notes, the major triad steps down in quarter notes, so adding emphasis to the tonic change. Nor is this the only work in which Lajtha applies the "I am a poor lad" melody. The eighth movement (titled Children's Play Song) of his early piano pieces Mesék (op. 2) of 1914 has it, while in his 1942 String Quartet no. 6 (op. 36) it forms the main thematic material of the second movement (Lento). The complete melody appears in the central section of the movement, as in Quartet no. 7 , but here it leads into some disturbing motivic pieces. A possible explanation of this appears in Lajtha's correspondence. In one letter of 1948, Lajtha calls himself a soldier: not a mercenary, not a condittore, as he puts it, but "a poor Hungarian lad" fighting the struggles of life. ${ }^{25}$ To an extent the song symbolizes the composer himself. In the second movement (Molto tranquillo) of the string quartet, its melody sounds optimistic, as the musico-political context demands, using the major instead of the minor. Indeed this gesture may reflect a work by Ferenc Szabó, whose 1949-1950 music for the film Lúdas Matyi also became an orchestral suite. In the second movement, "Peasant destiny", Szabó uses "I am a poor lad" as his theme. Here the rhythm varies - not in eighth notes, but in a time signature of $6 / 8$ (Examples 1-3).

Lajtha's folkloric second movement is followed by a limping minuet with a varying meter. A measure in $2 / 4$ is followed by one in $3 / 4$, to give a strange, humorous clumsiness. This unwonted effect is frequent in Lajtha's works: his opera 
ExAmPle 1 Lajtha, String Quartet no 6. (op. 36), mov. 2, mm. 28-29
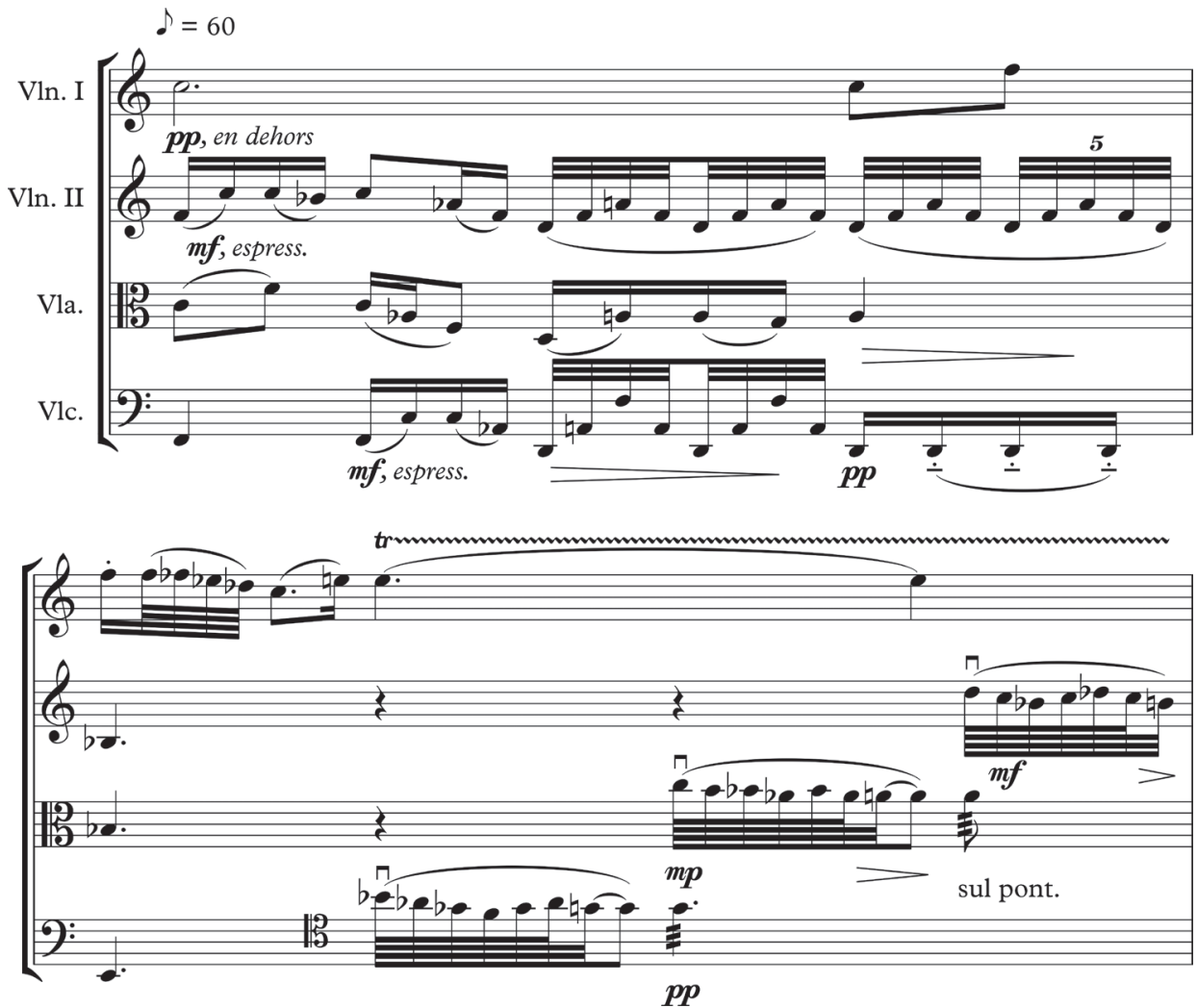

Le Chapeau bleu assigns a 5/4 meter to a comic figure, the servant. ${ }^{26}$ Another minuet is found in his 1955 Symphony no. 6. Its third movement is a minuet, but its mood differs sharply from what appears in the string quartet. The form is still tripartite, but the middle section backs away from the dance-like theme. Taking all this into consideration - as Emőke Tari Solymosi remarks - the minuet of the String Quartet no. 7 is the most conventional in Lajtha's œuvre. Elsewhere the minuet reprise is always changed to some extent, but in the string quartet a $d a$ capo form is used. ${ }^{27}$ Solymosi, in stressing how singular this is, retails a story told by one of Lajtha's colleagues, Henry Barraud. Lajtha said of musical form: "Never do a thing that could have been done by a copyist." 28 Solymosi saw the singularity of form in the whole œuvre, but did not raise the possibility of irony. Thus it seems

26. Emőke Tari Solymosi, Lajtha László színpadi müvei. Egy ismeretlen mücsoport a szerzői életút kontextusában [The stage works of László Lajtha. An unknown group of works in the context of the author's life] (PhD diss., Budapest: Liszt Academy of Music, 2011), 173.

27. Ibid., 188 .

28. Ibid. 
ExAmPLe 2 Lajtha, String Quartet no. 7 (op. 49), mov. 2, mm. 28-31
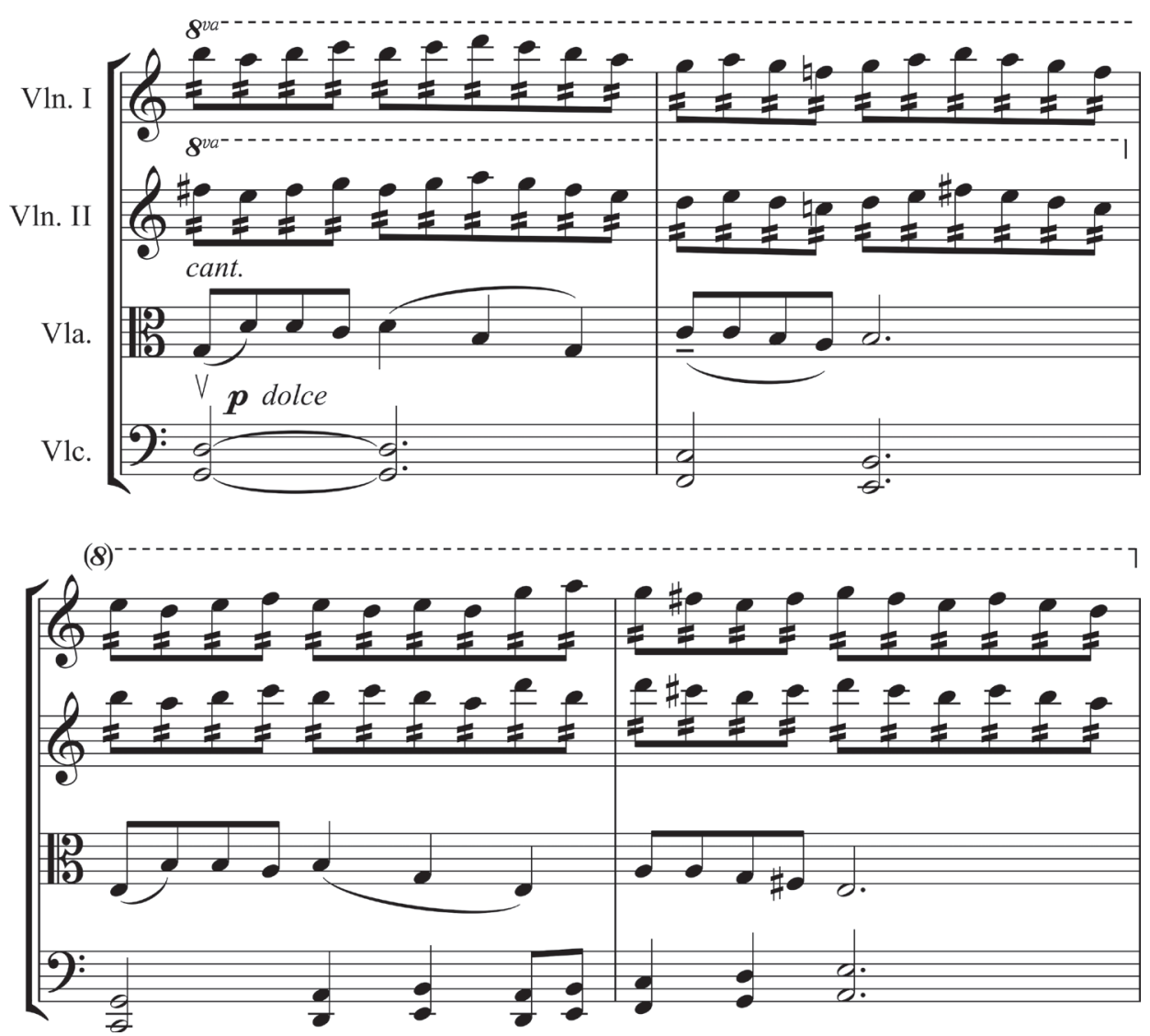

more than an accident that Lajtha should make didactic use in String Quartet no. 7 of a conventional sonata form, embed a major passage into an originally minor song, and add a regular minuet with da capo as a copyist might have done.

The solutions to the final movement recall the classical era, above all the style of Mozart's chamber works. Features to mention include the first theme of regular four-measure periods and a broad, rondo-like melody. The feel of the accompaniment also resembles this in its ornamented figures. Moreover, there appears a folk tune in the cello part. From measure 20, an upward major triad is heard, ornamented on its second appearance with eighth notes that densen the texture. This event is well known in classical style and found in many Mozart chamber works - for example the first movement of his Flute Quartet in D major (K 285), where the ornamentation foreshadows Lajtha's. In measure 51, the melody shows up and is then ornamented densened rhythmically for its second appearance. Both movements are in D major, the motif appearing in the tonic in Lajtha and the dominant in Mozart. So Lajtha ends his work in a style tied to the classical in several ways (Examples 4-5). 
Example 3 Szabó, Lúdas Matyi Suite, mov. 2, mm. 1-10

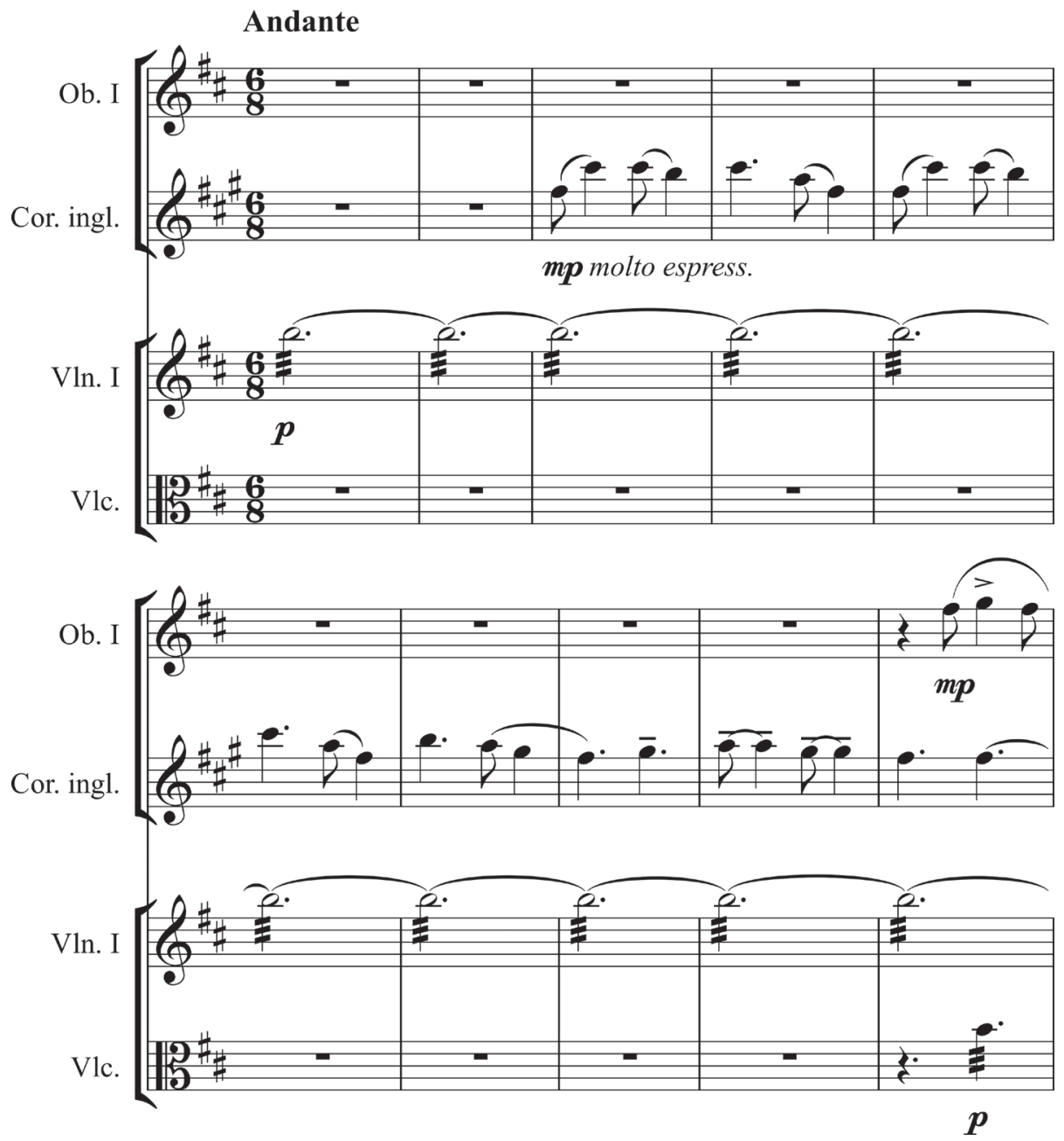

Lajtha regarded Mozart's works as ideals and models, and refers to Mozart many times in his letters. Indeed Emőke Tari Solymosi noted an interesting aspect of a lecture Lajtha gave in 1941 for the 150th anniversary of Mozart's death, ${ }^{29}$ where he described him as a "gentle soul, who reacts easily to all effects of the environment. Sensitive, receiving many things, whose soul and art were enriched by life itself." ${ }^{30}$ In 1962, Zsuzsanna Erdélyi recorded Lajtha's view of himself: "I re-

29. Ibid., 117.

30. Emőke Tari Solymosi, "Lajtha László előadása Mozartról a Nemzeti Zenedében Mozart halálának 150. évfordulója alkalmából megtartott hangversenyen (1941)" [Lajtha's lecture on Mozart at the concert to mark the 150th anniversary of his death (1941)], Magyar Zene 42/1 (February 2004), 82-86. 
ExAmPLE 4 Lajtha, String Quartet no. 7 (op. 49), mov. 4, mm. 21-24

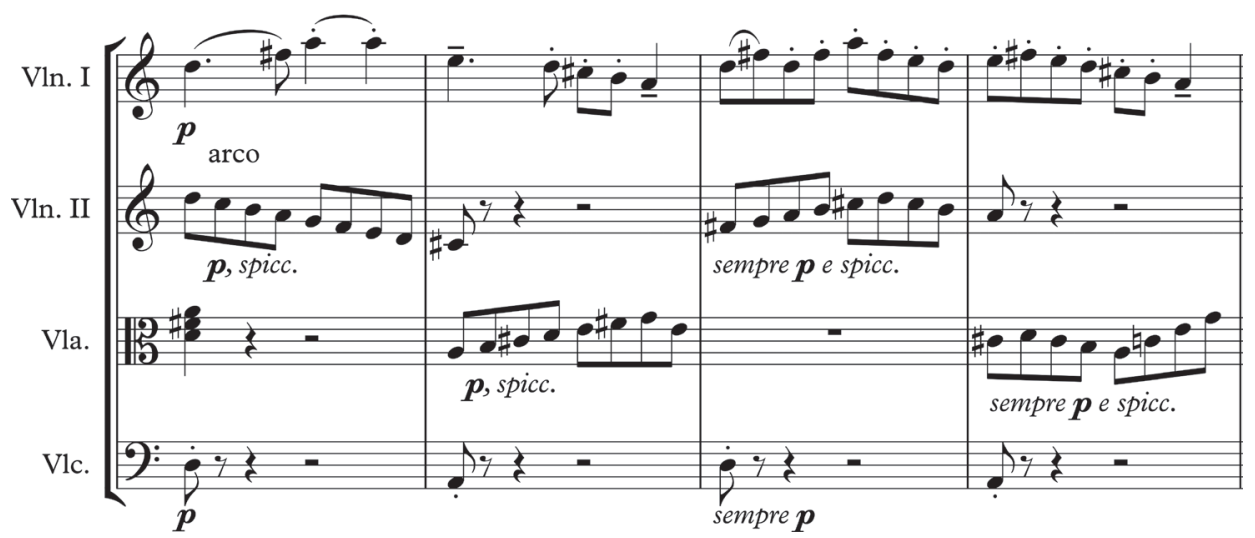

Example 5 Mozart, Flute Quartet in D major (K. 285), mov. 1, mm. 51-54
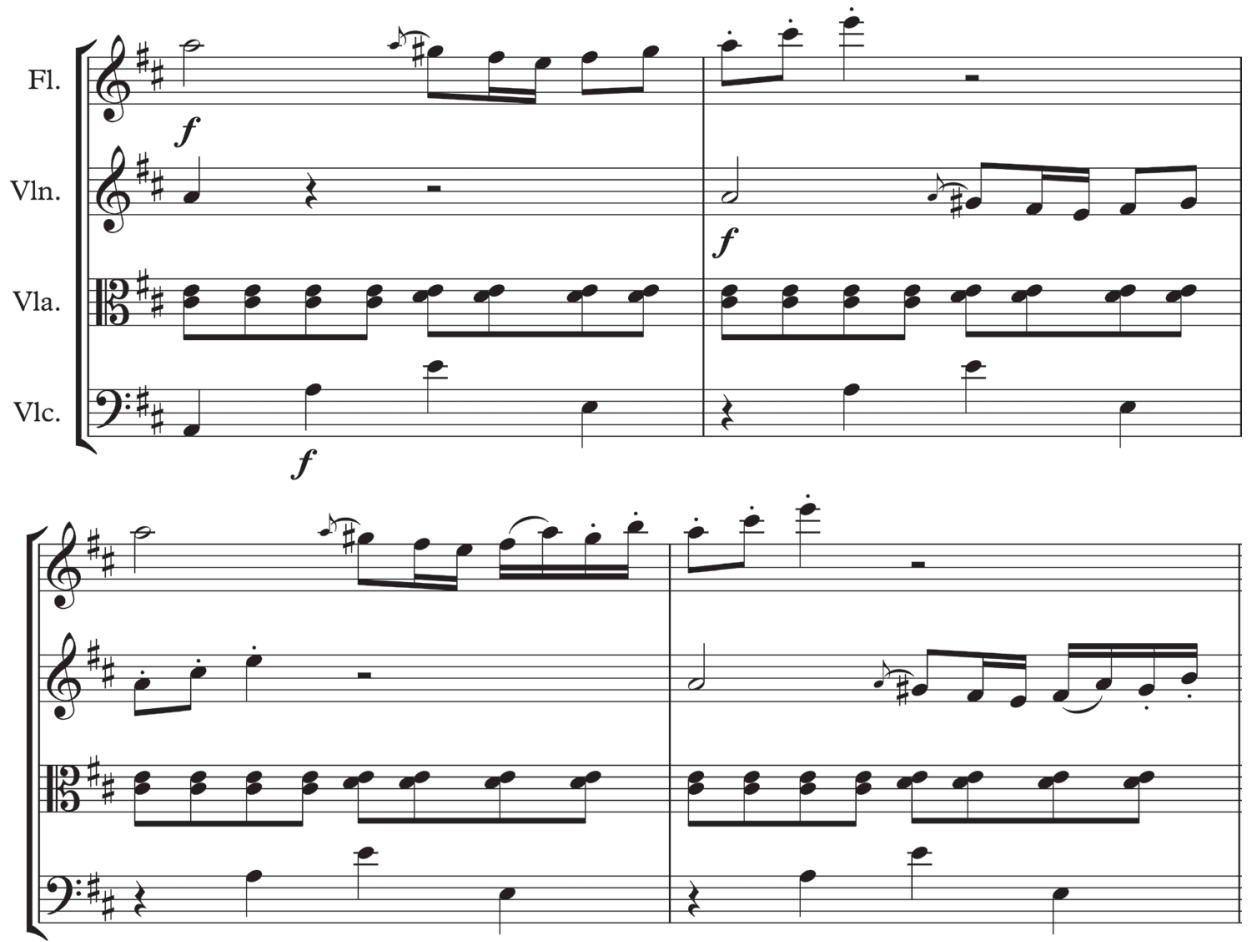
acted to every outward effect - nature, art, human - up to the most gentle move. Nowadays, at the age of 70, I am as sensitive as I have ever been ..." ${ }^{31}$ Further consideration of Solymosi's observation reveals more, similar overlaps in Lajtha's statements on Mozart, of whose humor he writes:

$\mathrm{He}$ is able to laugh at every human idiosyncrasy and everything amuses him. In the gravest minutes of his life he writes happy letters to his wife, not to comfort her, but because he has an irresistible need to laugh. His jokes often verge on vulgar buffoonery in life and in music. This broad pleasure spreads from a gentle, witty smile to a trivial laugh, and sometimes shows a kind of Leonardian smile, where smile and tears exist together. ${ }^{32}$

Some such sentences could fit a Lajtha biography unchanged. "In the gravest minutes of his life" he himself "writes happy letters to his wife" and "his jokes often verge on vulgar buffoonery." He himself gives example of how "smiles and tears coexist." In 1962, he wrote to his wife of his plans for his "Wilmslow" Symphony no. 10, Wilmslow being an English town near Manchester, where he met his sons and daughters-in-law in 1962, after being separated from them for all of fourteen years. ${ }^{33}$ As Lajtha put it: "If there is a chance for me to compose a symphony with smile and tears, it will be called 'Wilmslow'." All these details help to illuminate the importance to Lajtha of the Classical ideal.

In a report on String Quartet no. 7, Ferenc Szabó emphasized the inspiration from Hungarian folk music and welcomed how Lajtha's style had changed and he had begun to reject "the soul of European formalism and cosmopolitanism." 34 Half a year later, in the daily Magyar Nemzet on May 8, 1952, Sándor Asztalos wrote of Lajtha's quartet:

Last year, László Lajtha, after long silence, especially over String Quartet no. 7, proved one of the great masters in Hungarian musical life, indeed in a worldwide context. This new, fresh voice fulfilled in the love of life is a major outcome in our musical art, serving to prove the power of our socialist system to offer inspire to work and composition. ${ }^{35}$

31. Zsuzsanna Erdélyi, A kockás füzet. Úttalan utakon Lajtha Lászlóval [The squared notebook. On pathless routes with László Lajtha], edited by Emöke Tari Solymosi (Budapest: Hagyományok Háza, 2010).

32. Tari Solymosi, "Lajtha László előadása," 85.

33. Lajtha's undated letter to his wife (H-Bami, shelf-mark: MZA-LL-Script 8.621).

34. Ferenc Szabó, “Az I. Magyar Zenei Héten bemutatott müvek,” 14.

35. Sándor Asztalos, "Lajtha: VIII. vonósnégyes" [Lajtha’s String Quartet no. 8], Magyar Nemzet 8/106 (8 May 1952), 5. 
Asztalos writes also of Lajtha's early creative period and remarks on tension between the "democratism" of folk-music collecting and the "self-centered aristocratism fed by speculative sources" in the Western world. According to Asztalos, String Quartets nos. 7 and 8 must be warm welcomed for their solution to this opposition. His words suggest that he saw in Lajtha's work the new direction given by socialist realism. So Hungarian officialdom was clearly inclined to list Lajtha's String Quartet as a representative outcome of the changes in Hungarian musical life. Lajtha himself was content with the work, as were Szabó and Asztalos. On April 10, 1952, he wrote to his sons about an American performance of String Quartet no. 3 (op. 11) and its interpretation by the Curtis Quartet: ${ }^{36}$

It's a shame they played String Quartet no. 3. Your critic was right, my dear Ábel, and I'd like to know more of your sincere opinions on the slow movements. As I say, it's a shame they found this work, for my first two string quartets would have had greater success, and the two later string quartets 7 or 8 an even greater one. These compositions must have been stayed on their repertoire. ${ }^{37}$

In comparing the ideological critics and Lajtha's own opinion, the same observation can be made as on the concurrent Hungarian discussion about Bartók's œuvre $^{38}$ and in Lajtha's private reports in his correspondence with John S. Weissmann. The official view and Lajtha's private opinion share many surface features. Lajtha found himself on the same side as the leading circles in Hungarian musico-political life in his aesthetic preferences, but the way he arrived at them differed entirely, being based on purely artistic ideals.

\section{String Quartet no. 10}

This piece completed in 1953 turned out to be Lajtha's last in the genre. Despite the folk music material reused in it, this string quartet differs from the preconceived, officially required folklore suites and melody collections. Its musical material and arrangement of folk music add to knowledge of the relation between it and classical music. Lajtha wrote of his string quartets and their inspirations in a letter from September 1954. He cites a specific collection trip and even names his informant: Vencel Kristóf, a fiddler in Körispatak, where he led a folk music

36. The Curtis Quartet was formed in 1932 in Philadelphia by ex-students at Curtis Institute of Music.

37. Lajtha's letter to his sons on April 10, 1952 (H-Bami, shelf mark: MZA-LL-Script 8.343:2).

38. For the Bartók discussion, see Danielle Fosler-Lussier, "Bartók's Concerto for Orchestra and the demise of Hungary's 'third road'," in Music Divided: Bartók's Legacy in Cold War Culture (Berkeley, Los Angeles and London: University of California Press, 2007), 1-27. 
band. ${ }^{39}$ They played the tunes which Lajtha arranged as the musical material of String Quartet no. $10{ }^{40}$ Körispataki gyüjtés (Körispatak collection) is volume 3 of the Népzenei monográfiák (Folk music monographs) series, edited by Lajtha and his folk-music collecting group. Yet it is not always easy to identify the melodies, which he changed metrically or structurally for the string quartet. ${ }^{41}$ The subtitle "Dances from Udvarhelyszék" also refers to the collecting trips. Such collection was barred in Transylvania from 1919 to 1940 for political reasons, but some field work of importance was done between 1940 and 1944, when Lajtha and his group joined others collecting in Szék (Sic) and Körispatak. ${ }^{42}$ Some of them were arranged by the composer for folk orchestra for monetary reasons, such as "Four Dances from Udvarhely (Odorheiu)" and "Dances from Udvarhely" in 1952, ${ }^{43}$ to the second of which he gave no opus number, though the casual project may have instigated the string quartet, where he reused some. Some of the same tunes recurred in the string quartet, but there, embedded in grand art, he could take material to a higher artistic level. Lajtha states in a letter how he found "more art" in the melodies than he expected of a folk band. ${ }^{44}$ In a letter of July 20, 1953, he reports on his work process: "That 10th Quartet is not so easy as I thought. Now, as I try to close up on it, I see it doesn't give in for free." ${ }^{\text {45 }}$ Over a year later, on September 17, 1954, he called it "the first folk-song arrangement I gave an opus number." ${ }^{, 6}$ Ensuing passages in the letter refer to deeply emotional, personal motives behind the Quartet. It is notable that he arranged not only folk songs, but instrumental folk music. This folk-music and collecting trip was well-known to Lajtha's sons, notably Ábel, who had joined it himself. So the String Quartet no. 10 shows well how scholarship and composing, official duties and personal life, are entwined.

Though the periodical Szinház és Mozi called the première in 1954 a "notable event," press coverage was rather scant. ${ }^{47}$ Critics at the time associated the work with other classical styles, not just folk music. On October 21, 1954, the critic "W. A." in Magyar Nemzet speaks of a sound "rioting in colors on a small orchestra that even evokes Richard Strauss" and "reminiscences of a Midsummer

39. Lajtha's letter to his sons on September 17, 1954 (H-Bami, shelf mark: MZA-LL-Script 8.378:2).

40. There is one place where Géza Péter, not Vencel Kristóf, played the melody arranged by Lajtha in the first movement. On this record Kristóf played the double bass.

41. László Lajtha, Népzenei monográfiák III. - Körispataki gyüjtés [Folk music monographs III. - Körispatak collection] (Budapest: Zeneműkiadó, 1955).

42. Melinda Berlász, "Dokumentumok az 1940-1944-es erdélyi gyűjtések és hanglemezfelvételezések történetéhez" [Documents to the history of the 1940-1944 Transylvanian collections and disc recordings], Magyar Zene 33/2 (June 1992), 115-137.

43. Lajtha's letter to his sons on 17 September, 1954 (H-Bami, shelf mark: MZA-LL-Script 8.378:2).

44. Ibid.

45. Lajtha's letter to his wife on July 10, 1953 (H-Bami, shelf mark: MZA-LL-Script 8.361:2).

46. Lajtha's letter to his sons on 17 September, 1954 (H-Bami, shelf mark: MZA-LL-Script 8.378:2).

47. N. N., "Ilyen lesz az öszi hangversenyévad" [This is how the fall concert season will be], Színház és Mozi 7/36 (September 1954), 22. 
TABle 3 Melodies from Körispatak collection in the String Quartet no. 10

\begin{tabular}{|c|c|c|}
\hline $\begin{array}{l}\text { String Quartet } \\
\text { no. } 10 \text { - } \\
\text { Movement, number } \\
\text { of measures or } \\
\text { character }\end{array}$ & $\begin{array}{l}\text { Körispataki gyüjtés - } \\
\text { Number and name of } \\
\text { the dance }\end{array}$ & Notices in Körispataki gyüjtés \\
\hline mov. $1, \mathrm{~mm} .1-12$ & $\begin{array}{l}\text { 34. Erdélyes lassú } \\
\text { [Transylvanian slow } \\
\text { dance] }\end{array}$ & $\begin{array}{l}\text { "Szeress, szeress, csak nézd meg kit" } \\
\text { ["Love, but be careful, who you love"] }\end{array}$ \\
\hline mov. 1, mm. 30-53 & $\begin{array}{l}\text { 21. Marosszéki [From } \\
\text { Marosszék] }\end{array}$ & $\begin{array}{l}\text { Géza Péter plays the violin, Vencel Kristóf the } \\
\text { double bass. "He pulls the bow strongly, so it } \\
\text { touches the neighbouring string." }\end{array}$ \\
\hline mov. 2, Plus vite & $\begin{array}{l}\text { 27. Sebes csárdás } \\
\text { [Fast csárdás] }\end{array}$ & $\begin{array}{l}\text { Lajtha's remarks on the change between "reája" } \\
\text { and figurája". }\end{array}$ \\
\hline mov. 2 , très tendre & $\begin{array}{l}\text { 36. Erdélyes lassú } \\
\text { [Transylvanian slow } \\
\text { dance] }\end{array}$ & - \\
\hline mov. 3, mm. 1-3 & 32. Erdélyes lassú & $\begin{array}{l}\text { "Jazt gondoltam, amíg élek" ["I have always } \\
\text { thought so that as long as I live"] }\end{array}$ \\
\hline mov. 3, mm. 16-25 & 32. Erdélyes lassú & "De jén abba megcsalódtam" ["But I erred"] \\
\hline mov. 4, mm. 1-38 & \begin{tabular}{|l|} 
4. Erdélyes \\
[Transylvanian dance]
\end{tabular} & - \\
\hline mov. 4 , mm. $135 \mathrm{ff}$ & $\begin{array}{l}\text { 24. Cigánycsárdás, } \\
\text { gyors csárdás [Gypsy } \\
\text { csárdás, fast csárdás] }\end{array}$ & $\begin{array}{l}\text { Lajtha quotes Vencel Kristóf: "To Gipsy dance. } \\
\text { But we played on other opportunities, too. } \\
\text { Weddings are on Tuesday. The lad could not } \\
\text { go to the girl until he had hit an egg placed on } \\
\text { the top of a stake. So it went in the olden days. } \\
\text { It was a great amusement. Men danced and we } \\
\text { played this music." }\end{array}$ \\
\hline
\end{tabular}

Night's Dream". Yet "this work by Lajtha is a precious gain to string-quartet literature" and the part of the first violin "a musical delicacy". 48

Still, the inspiration gained from folk music defines the characters of the movements. The fast csárdás (no. 24) plays an important dramaturgical role in the work. This melody, as the second thematic part of the final movement, sums up the quartet. Its role is so emphatic partly because Lajtha aimed to give the work to his sons and their wives as a wedding gift, to show them how a Hungarian wedding really sounds.

The relation between melody and accompaniment is the same as in original folk-dance music. The melody is presented by the band leader or primás (first violin) and others begin to play only after they catch the melody. This is richly

48. W. A. [Alajos Werner?], "A Tátrai-vonósnégyes hangversenye” [Concert of the Tátrai String Quartet], Magyar Nemzet 10/249 (21 October, 1954), 5. 
ornamented and expressed by the primás over held harmonies. An important difference between the folk tunes and the classical adaptation is that in the second it is not always the first violinist who plays the melody first. The theme may appear in any part of the composition and be presented by a cellist or viola player. This variety influences the soundscape in a positive direction, but sidesteps the classic generic tradition of complex poliphony in the material. Instead of a coordinate relation, Lajtha uses subordinate parts in the structure. The hierarchy is always perceptible: during the melodic units, only one instrument plays the leading role. The folk melody is allowed to flow without any artifice or composer intervention. The solo parts are often restricted to the form found on the written record sheet.

Turning to harmonization, some unusual solutions can be seen. Some dissonant harmonies emerge, somewhat outrageously in places where the original tune contains tonal harmonies. For example, the melody on the main beat of measure 25 in the first movement places ornamentation around $\mathrm{C}$, while the accompanying instruments play A-D-G-E flat (Example 6). There is no trace of such sharp dissonance or a figure "out of tune" at the same place in the original melody: measure 11 of melody 34 in Körispataki gyüjtés. The D in the bass and the surmounting $\mathrm{C}$ major triad simply form a ninth chord with a missing seventh. Alternatively, this can be gauged as a simple $\mathrm{C}$ major triad with a foreign bass left in from the previous chord (Example 7). Quite the same appears in the middle section of the second movement. The melody is again ornamented around $\mathrm{C}$ and a C-sharp minor triad figures in the accompaniment. This chord links an E minor triad and a D major triad, so that it can be seen as ornamentation before the real bass $\mathrm{D}$ takes its place.

Lajtha, in the preface to Körispataki gyüjtés, describes the use of this performance technique in Hungarian folk style. ${ }^{49} \mathrm{He}$ identifies the role played by the kontra and a cello called the kisbögö - "little bass" - and asserts that their rhythmic function takes precedence over the harmonic one. This rhythmic figure or ostinato can free itself from the melody line and sound strange chords hard to identify in terms of classical harmony. The style of playing by the band from Körispatak also gave Lajtha a chance to express views on the tonal issues raised by a folk band. In 1953, while preoccupied with composing the String Quartet no. 10, Lajtha wrote an essay entitled "A band 'out of tune.". 50 Details from the text appear also in the 1955 preface to Körispataki gyüjtés and it seems he found this kind of interpretation important. ${ }^{51} \mathrm{He}$ makes it clear that the out-of-tune sound can arise from a simple mistake: one player hits a wrong note while the others play the right one. This mistaken dissonance Lajtha incorporated into his folklore

49. Lajtha, Körispataki gyüjtés, 8.

50. László Lajtha, "Egy »hamis« zenekar" [A band "out of tune"], in Bence Szabolcsi and Dénes Bartha (eds.), Zenetudományi tanulmányok I. Emlékkönyv Kodály Zoltán születésének hetvenedik évfordulója alkalmából [Musicological studies 1. Memorial volume for the 70th anniversary of the birth of Zoltán Kodály] (Budapest: Akadémiai Kiadó, 1953), 169-199.

51. Lajtha, Körispataki gyüjtés, 5. 
ExAmPLE 6 Lajtha, String Quartet no. 10 (op. 58), mov. 1, m. 25

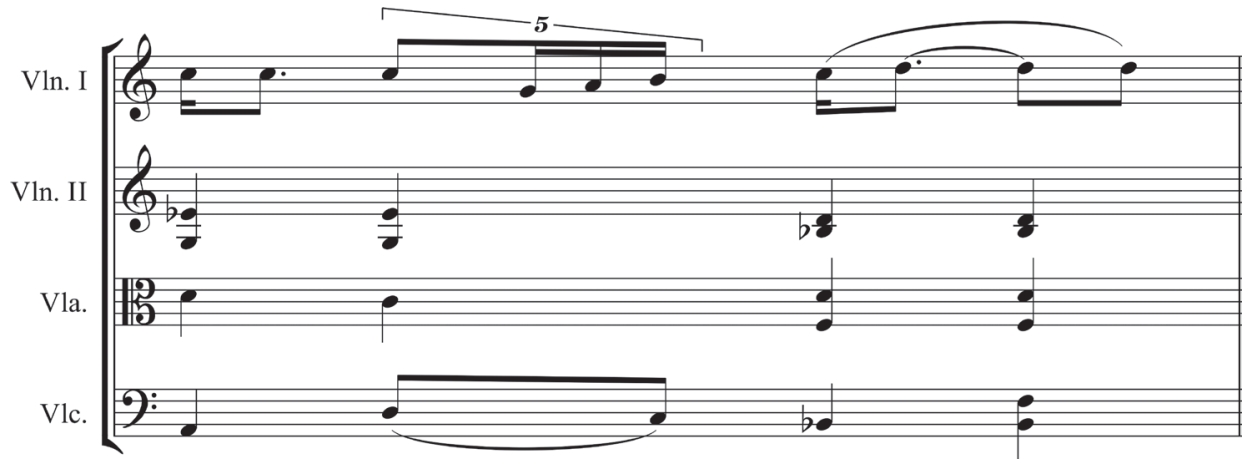

Example 7 Lajtha, Körispatak Collection, no. 34, m. 11

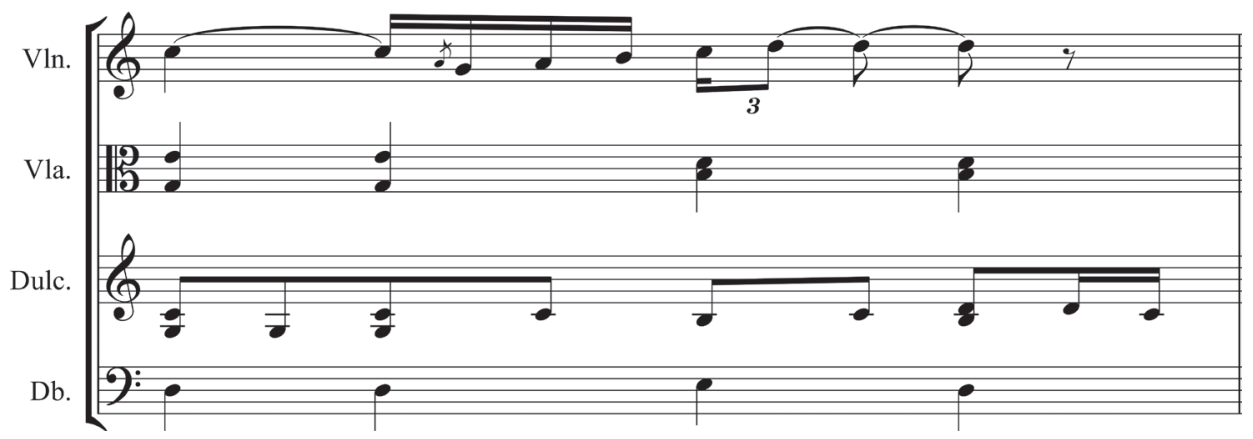

atmosphere. He was not making a musical joke here, merely striving to retrieve a personal experience - a style far from familiar to the wider public or even to musicians who had never done any collecting themselves. This verdict is not prompted only by the elegance or severity of the music. Lajtha's Körispataki gyüjtés preface states not all folk musicians are local Dorfmusikanten. Some are musicians with plenty of stylistic knowledge and very good technical skills - only as a band do they play "right out of tune" in a harmonic sense. ${ }^{52}$ The feature is not unique, for Lajtha himself met players from other villages using the same harmonization. He recalls a band from Nógrád County whose instruments - violin, clarinet, cimbalom, kontra and double bass - played separately from each other. Melody and harmony often fell apart or the melody itself came in several forms, depending on the ornamenting in the different instrumental parts. ${ }^{53}$

Besides the harmonization, it is also worth analyzing the ornamentation and the notation of the melody. The notation in the original record and in the classical 
score can differ in some respects. Lajtha himself referred to the importance of notating the ornamentation properly. This he saw as the only way to ensure that musicians educated in classical music play the folk music in its appropriate style and to avoid any further misunderstanding of it. ${ }^{54}$ Here Lajtha draws a parallel between folk music and Baroque music: in both the performer is free to play or sing ornamentation and treat the melody differently, for the music has no final, unchangeable form. There is a style or tradition of folk music or Baroque music, within whose frames musicians can vary the musical text spontaneously. But musicians who have never played folk music before and were not born into the tradition have to be guided precisely and need as much score information as possible, if they are to reproduce the way in which a folk musician plays. To return to our immediate subject: String Quartet no. 10 and the other arrangement, Udvarhelyi táncok, reflect the notation of the original record in many places. One essential difference is that the quartet provides all the parts with soloistic material, whereas Udvarhelyi táncok gives a soloistic role only to the first violin.

ExAmPle 8 Lajtha, Körispatak Collection, no. 32, mm. 1-6

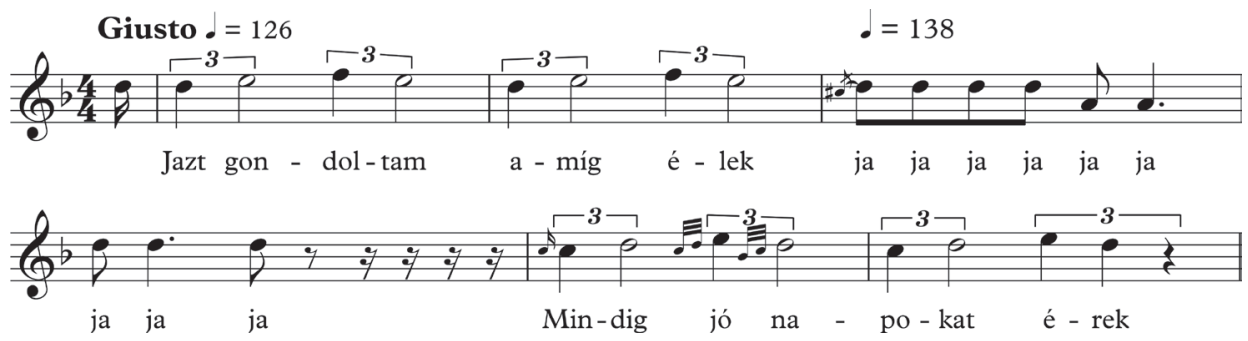

ExAMPLE 9 Lajtha, String Quartet no. 10 (op. 58), mov. 3, mm. 1-5

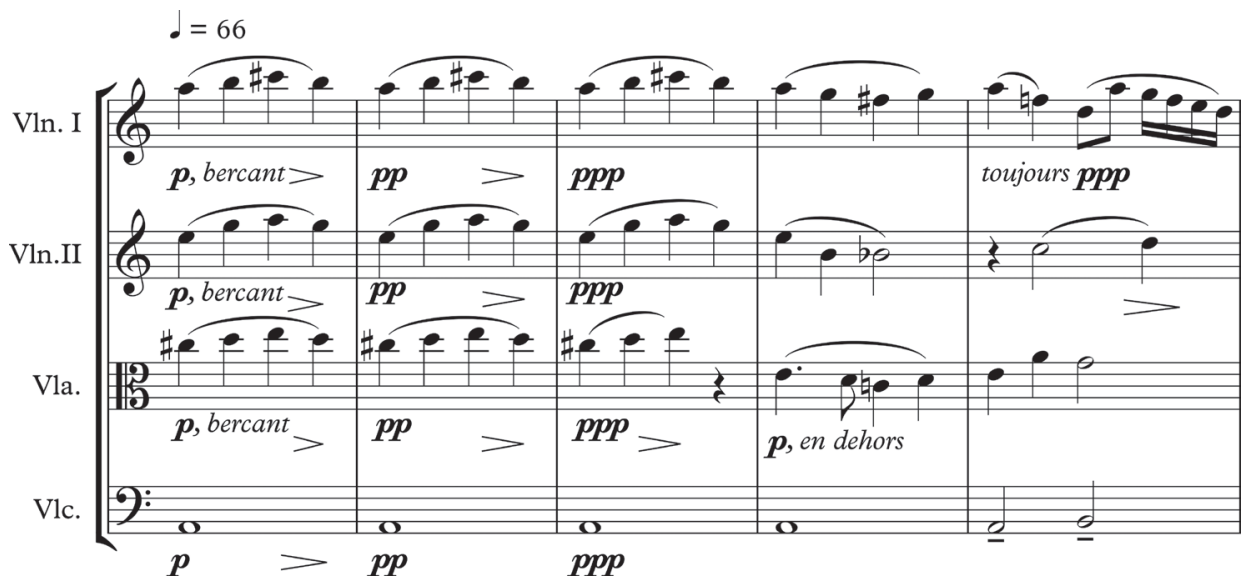

54. Ibid., 5. 
In the letter quoted Lajtha writes: "If you listen to [the quartet] - and I believe you will listen to it - your wives' hearts will be sore. I made it that way." ${ }^{\prime 5}$ His words suggest the quartet was created a little self-consciously. Yet the music itself proves that Lajtha managed to place into it his own inward sadness. The third movement forms a traditional slow-fast pair of sections. The slow begins like a lullaby and recalls Trois berceuses, composed in the same period (1955-1957) for the composer's young grandchildren living far from Hungary. This tie is reiterated in the expression "berçant". The initial, gently rocking figure stems from Körispataki gyüjtés. The melody fits the first two lines of a folk song: "I have always thought that as long as I live / I'll have pleasure in my days" (Examples 8-9). The third and fourth lines - "But I erred and now am apart from my loved one" - come much later, from measure 16 in the second-violin part (Examples 10-11). Clearly Lajtha was thinking not just of a sad love affair, but of his forced separation from his beloved sons, with no chance of knowing their wives or his grandchildren. The melody weaves into the texture in two parts distant from each other, horizontally and vertically. The first two lines - so to say positive thoughts - come as a special accompaniment, but the third and fourth lines have sadness and separation in the present appear as the main melody on a solo instrument.

ExAmPLE 10 Lajtha, Körispatak Collection, no. 32, mm. 9-10

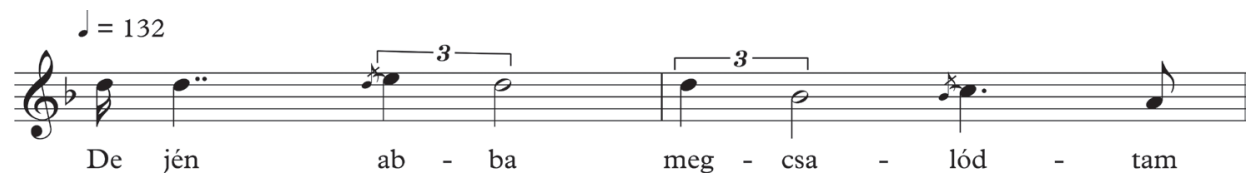

ExAmple 11 Lajtha, String Quartet no. 10 (op. 58), mov. 3, mm. 16-17

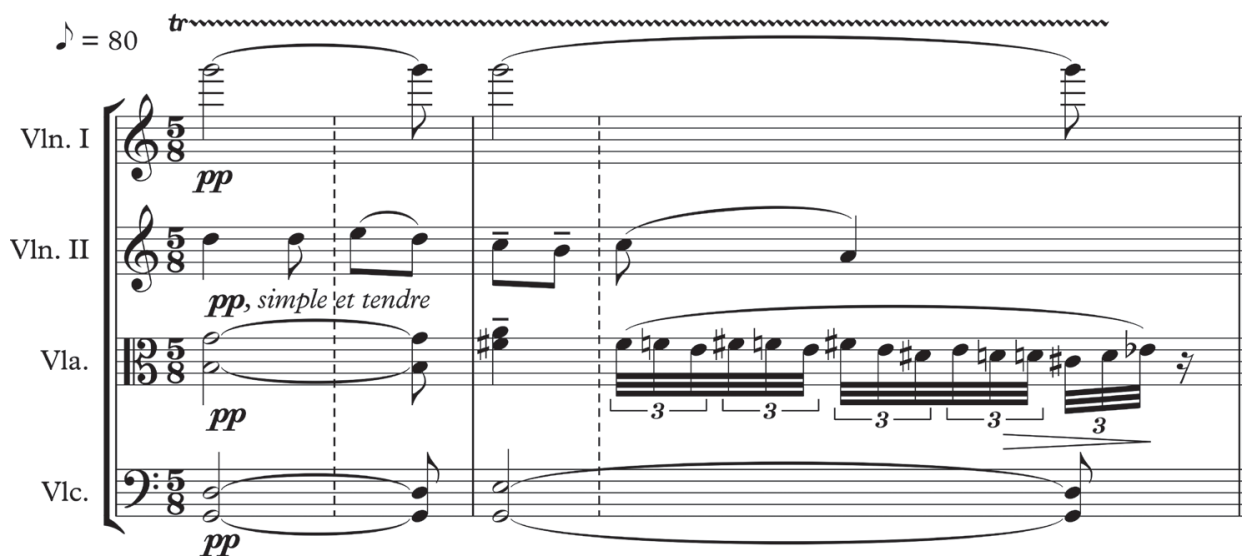

55. Lajtha's letter to his sons on 17 September, 1954 (H-Bami, shelf mark: MZA-LL-Script 8.378:2). 
It has been seen how Lajtha, in String Quartet no. 7, stressed the connection between folk music and classical art in rather external ways. I see this as an ironic gesture toward the demands of the official rules, or an attempt to find an acceptable compromise. However, String Quartet no. 10 shows different features, as it conveys intimate feelings and tells a personal story through the music - with notably tight strings to Lajtha's personal life and deepest emotions in the third movement. This provides a fine example of how to bind together ritual folk music and aesthetic classical music, despite their functional differences, and so entwine collective and individual art. Lajtha composed String Quartet no. 10 as a present, a memento: the music brings his personal and family life alongside folk music, through his scholarly œuvre. The two are bound together by their strong emotional content. And at this point let us again quote Lajtha's own words: "Every single artist who creates his own psychological world, feels the need to belong somewhere." $" 56$ 